\title{
工作機械における湿式切削時の熱同期制御に関する研究 (ニューラルネットワークの逆解法を用いたコントロール)
}

\author{
田辺 郁男*1，西山 晃 ${ }^{* 2}$, 五宝 純一*3, 高橋 智*1
}

\section{Research on control using thermal synchronism at wet cutting in machine tool (Control using inverse analysis of neural network)}

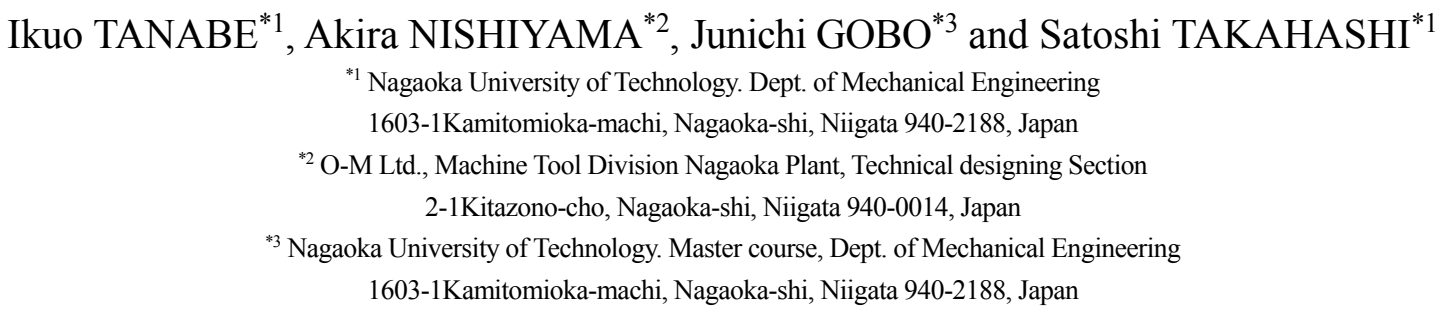

Received: 19 September 2016; Revised: 21 April 2017; Accepted: 5 June 2017

\begin{abstract}
As accuracy of industrial product was reduced by thermal deformation of a machine tool, a tool and a workpiece during cutting, there are several countermeasures for machining field. In the old days, we had developed and evaluated for a lathe with insensibility function for thermal and temperature change. The lathe has the structure of zero-center on three directions, the structure of self-compulsory cooling and the structure of thermal synchronism. Particularly the structure of thermal synchronism was developed for wet cutting. However the control method for the structure of thermal synchronism was yet to establish. Therefore the control using thermal synchronism at wet cutting in machine tool was developed and evaluated. The control system of fluid quantity on the structure of thermal synchronism using inverse analysis of neural network was developed for insensibility function of thermal and temperature change. Then thermal deformations of the developed lathe were measured and evaluated in the several experiments. It is concluded from the results that; (1) Thermal deformation of the bench lathe was very small in spite of no-forced cooling, (2) The control system of fluid quantity on the thermal synchronism using inverse analysis of neural network was effective for its working stability during wet cutting.
\end{abstract}

Key words : Forced cooling, Machine tool, High accuracy, Inverse analysis of neural network, Cutting

\section{1. 緒言}

高精度な加工のために多くの熱変形対策が工作機械に施されている(田辺他，2003). また，高精度化と生産性向 上のために切削発熱の強制冷却技術も確立されている(田辺他，2011),(田辺他，2000a),(田辺他，2001). これらの 対策には，強制冷却による熱変形の抑制対策(金子他，2004)のほかに，工作機械の熱変形補正( Mayr, 2012)，熱変 形予測のためのニューラルネットワークの使用 (森脇他，1995)，最適な冷却制御方法(千輝，垣野，1987)などの 研究が行われている．また，現在，地球環境保全に配慮したものづくり(田辺，折茂，2001)がごく一般的に要求さ れるようになってきており，21 世紀型加工技術として，高精度，高生産性，高信頼性に加えて，環境保全に配慮 したものづくりが必要とされている。一方，著者らは強制冷却を行わなくても加工精度が維持できる熱不感構造 （三次元零芯構造，セルフ強制冷却構造，熱同期構造）の工作機械を開発している(田辺他，1999). しかし，現時 点で，湿式切削の際に利用される熱同期構造において，完全に熱変形を同期させるコントロールができていない ことが大きな欠点として挙げられる.

No.16-00449 [DOI:10.1299/transjsme.16-00449], J-STAGE Advance Publication date : 16 June, 2017

*1 正員，長岡技術科学大学（干940-2188 新潟県長岡市上富岡町 1603-1)

*2 (株) オ一エム製作所（干940-0014 新潟県長岡市北園町 2-1）

*3 長岡技術科学大学 工学部

E-mail of corresponding author: tanabe@mech.nagaokaut.ac.jp 
そこで本研究では, 旋盤において, 湿式切削時に温度上昇した切削油剤が刃物台にかかり熱変形するのに対して, 同じ切削油剤を主軸側の構造内にも循環させることで，刃物と工作物の相対変位を相殺する手法の確立を目的と する. 具体的には, 熱同期構造を搭載した卓上旋盤を使用し, 湿式切削の際に切削油剤を循環される冷却経路内 の冷却油剤の流量をニューラルネットワークの逆解法で制御する方法を構築し, その有効性を評価する.その後, 本手法の簡単な LCA 計算を行い，工業的な妥当性も評価する．なお，本報の手法を省エネルギー対策のみでな く，環境保全に充分配慮した対策にするために，冷却油剤は強アルカリ水を使用することにする.

\section{2. 熱同期構造と冷却媒体としての強アルカリ水の説明}

ここで, 著者らは以前に開発した熱不感構造（三次元零芯構造, セルフ強制冷却構造, 熱同期構造）（田辺他， 1999)の中から，本報で研究対象とする熱同期構造について簡単に説明する.

図 1 に熱同期構造の概略を示す．熱同期構造とは，湿式切削を行った場合に刃物台に温度上昇した切削油剤が かかり Y 方向に熱変形するのに対して，主軸台もその切削油剤の熱を利用して Y 方向に熱変形させ，その $2 つ$ の熱変形を同期させることにより，主軸中心線と工具の相対的熱変位を小さくする構造である. 具体的には，ポ ンプから刃物台までの切削油剤の循環経路の間に，ベッド上に搭載した脚 B， B'に開けた穴に切削油剤が通るよ うにバイパスさせて, 刃物台の上方（Y 方向）への熱変形と主軸台の上方への熱変形を同期させ，キャンセルさ せるものである．この熱同期構造の欠点として，負荷変動によって主軸軸受の発熱量が変動すること，また刃物 台の上方 $(\mathrm{Y}$ 方向 $)$ への熱変形と主軸台の上方への熱変形の完全な同期が困難なことから, その熱変形を完全に 抑制できないことが挙げられる.このように, 開発した熱不感構造によって, 強制冷却を行わなくても, 高い加 工精度を有する卓上旋盤を提案したが，構造設計だけでは熱変形を完全に抑制することが困難であった。

次に環境保全に配慮した対策のために使用寸る強アルカリ水について説明する.水の気化熱による冷却効果は, 切削油剤のそれに比べてきわめて大きい(田辺他, 2001)にも関わらず, 現状において工場内の工作機械に適用さ れている例は少ない. それは, 水が工作機械, 工作物, その周辺の機械要素などの鋼製部品を腐食させるためで ある. しかし, 腐食工学において平衡状態で金属イオン濃度（mol/l/ ）の対数值がー 6 以下のときにその金属は腐 食されないとみなされており, そのため, 鋼の強アルカリ水に対する腐食特性(下平，1995)に関しては, pH 10 以 上のアルカリ水中では腐食が起こらないことになる. よって $\mathrm{pH} 12.5$ を超える強アルカリ水は, 前記の鋼製部品を 腐食することはないと考えられる. そのため, 工作機械と工作物の両方を腐食することのない強アルカリ領域を 選択して利用寸ることで, 水の気化熱によって強制冷却させながら, 工作機械と工具への熱影響の軽減を行うこ とが可能と考えられる.ここでは, 工作物や工具のほか, 工作機械部品や工作機械関連の機械要素の而強アルカ リ特性を実験で明らかにする. 表 1 に実験で使用する強アルカリ水の仕様と健康安全性の調查結果を示す. 使用 する $\mathrm{pH} 12.5$ の強アルカリ水は小型の生成装置で, 極めて容易に生成することができる. これは, 水道水と炭酸 カリウム（軟石零, 硬質ガラス, 光学ガラスなどの製造原料, 染色, 漂白, 羊毛の洗濯などに使用される. ) を使

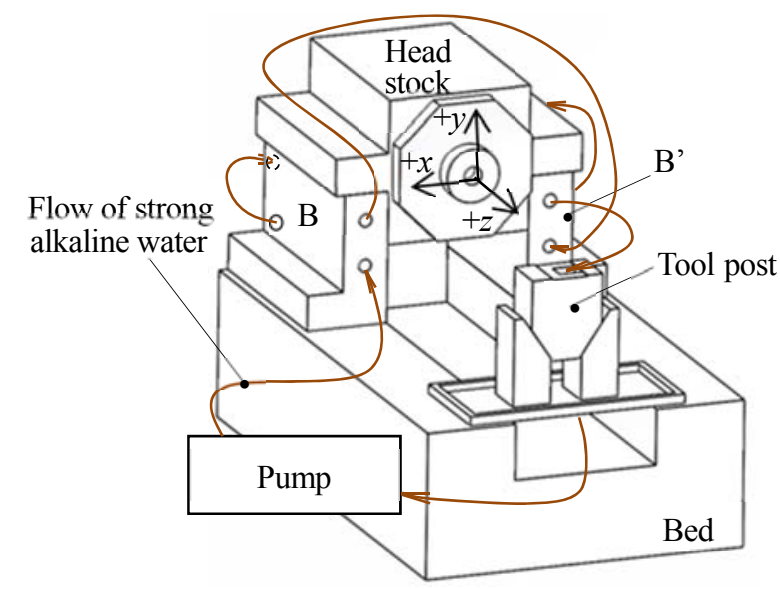

Table 1 Specification of strong alkaline water its safty of health.

\begin{tabular}{|l|l|l|}
\hline \multicolumn{2}{|l|}{ Method of generation } & Closed generation type \\
\hline \multicolumn{2}{|l|}{ Value of $\mathrm{pH}$} & $\mathrm{pH} 12.5$ \\
\hline \multicolumn{2}{|l|}{ Ingredient (Content) } & Potassium hydroxide $(0.18 \mathrm{w} / \mathrm{v} \%)$ \\
\hline Raw materials & Tap water \& Potassium carbonate \\
\hline \multirow{2}{*}{$\begin{array}{l}\text { Safety } \\
\text { of } \\
\text { health }\end{array}$} & Smell & Nothing (No problem) \\
\cline { 2 - 3 } & Touch & Wear gloves \& glasses (Avoid) \\
\cline { 2 - 3 } & Breath & Wear mask (Avoid) \\
\cline { 2 - 3 } & Drink & Prohibition \\
\hline
\end{tabular}

Fig.1 Schematic view for the structure of thermal synchronism. 
Table 2 The results of the materials tested in strong alkaline water with pH12.5 (for two month).

\begin{tabular}{|c|c|c|c|}
\hline Work piece materials & $\begin{array}{c}\text { Condition inside strong } \\
\text { alkaline water }\end{array}$ & Tool materials & $\begin{array}{l}\text { Condition inside strong } \\
\text { alkaline water }\end{array}$ \\
\hline \multirow{2}{*}{$\mathrm{Ti}$ (pure) } & \multirow{2}{*}{$\bigcirc$} & High speed tool & $\mathrm{O}$ \\
\hline & & Carbide (S30T, T725X) & $\mathrm{O}$ \\
\hline \multirow{2}{*}{ Ti6Al4V } & \multirow{2}{*}{ O } & Cermet (NS530) & $\mathrm{O}$ \\
\hline & & Ceramics (LX11) & $\mathrm{O}$ \\
\hline \multirow{2}{*}{ Inconel 718} & \multirow{2}{*}{ O } & CBN (KBN525) & $\mathrm{O}$ \\
\hline & & Diamond (DA2200) & 0 \\
\hline Steel (S45C) & O & $\begin{array}{c}\text { Coating materials of } \\
\text { tool } \\
\end{array}$ & $\begin{array}{c}\text { Condition inside strong } \\
\text { alkaline water }\end{array}$ \\
\hline Aluminum & $\bar{x}$ & TiN & $\mathrm{O}$ \\
\hline \multirow{2}{*}{ Copper } & \multirow{2}{*}{$\begin{array}{l}\text { Changed to } \\
\text { dark brown }\end{array}$} & $\mathrm{TiC}$ & 0 \\
\hline & & DLC & $\mathrm{O}$ \\
\hline \multirow{2}{*}{ Brass } & \multirow{2}{*}{$\begin{array}{l}\text { Changed to } \\
\text { dark green }\end{array}$} & TiAlN & $x$ \\
\hline & & TiAlCr & $x$ \\
\hline
\end{tabular}

用し， $0.18 \mathrm{w} / \mathrm{v} \%$ の水酸化カリウム溶液を生成するものであり，アミド結合を加水分解する性質がある. また, タンパク質を溶解する作用もあるため, 使用時に保護眼鏡，防塵マスク，保護手袋の着用が必要で，取扱い後は よく手を洗うことも必要である. なお, 強アルカリ水は界面浸透性, 剥離分解能力, 乳化・分離能力が大きいた め, 洗浄力が極めて大きく, 除菌・腐敗防止作用もあり, 広域におよぶ洗浄剤として最近よく使用されている. また, 強アルカリ水を大気中に放置し続けると, $\mathrm{pH}$ は 7.0 に漸近しアルカリ性を失いただの水になるため, 環境 保全を促進できる洗浄剤として注目されている.

而搔アルカリ特性の実験結果を表 2 に示寸．工作物としては，純チタン，チタン合金，ニッケル基合金のほか に, 工業製品としてよく使用されている鋼 $(\mathrm{S} 45 \mathrm{C})$, アルミニウム, 黄銅, 銅を, 工具材種としては, 高速度工具 鋼, 超硬, サーメット, セラミックス (アルミナ), CBN, ダイヤモンドを, また, 工具のコーティング材料とし ては, TiN, TiC, DLC, TiAlN, TiAlCrをそれぞれ試料として使用した. これらの材料を $\mathrm{pH} 12.5$ の強アルカリ水 の入った試験管に入れ, 室温 $20^{\circ} \mathrm{C}$, 湿度 $60 \%$ ，2 ケ月後の結果である. アルミニウム, アルミニウム合金, 銅, 銅合金以外の金属は，強アルカリ水中，および強アルカリ水面付近に 2 カ月間放置しても腐食しなかった. その ため, 鋼, チタン合金，ニッケル合金を強アルカリ水中に完全に浸漬した状態にして，切削加工を行うことが可 能であると考える. 本報では, 冷却管路内の熱伝達による冷却効果, 工作機械の腐食防止, バクテリア・カビ・ 菌の発生防止，環境保全のためにこの強アルカリ水を冷却媒体として使用寸ることにした.

\section{3. ニューラルネットワークの逆解法を用いた熱不感構造のコントロール方法の確立}

前章で説明した熱同期構造の欠点の対策として, ニューラルネットワークの逆解法(田辺他, 2000b)を用いてコ ントロールすることにした. それに先立ちここでは, ニューラルネットワークの逆解法を用いたコントロール方 法について説明する.

図 2 に工作機械として卓上旋盤のモデルを示す．稼働中の卓上旋盤は主軸軸受部を主熱源とし，構造各部の温 度上昇が熱変形を引き起こし，その結果加工精度が低下する。

図 3 に図 2 の卓上旋盤モデルを用いて構築した階層型ニューラルネットワークモデルを示す．ここでは，一般 的に良く使用される入力層, 中間層, 出力層からなる 3 層構造を用い, 中間層にはシグモイド関数, 出力層には 線形一次関数をそれぞれ用いているが, さらなる多層構造になった場合や, 中間層, 出力層にそれぞれ他の関数 が使用された場合でも理論的な問題はない. ニューラルネットワークの学習は, 教師データと出力データの差の 2 乗和が最小になるように, 最急降下法によりユニット間の結合関数 $W_{j i}, V_{k j}$ およびユニット間のオフセット値 $\beta_{j}, \gamma_{k}$ をプログラム内で逐次修正して求めるものである. ここで， $W_{j i}$ は入力層と中間層の結合関数， $V_{k j}$ は中間層 
と出力層の結合関数, $\beta_{j}$ は中間層に与えるオフセット值, $\gamma_{k}$ は出力層へ与えるオフセット值である. ここではバ ックプロパゲーション法を使用する．学習パターン $p$ の誤差関数 $E_{p}$ は

$$
E_{p}=\frac{1}{2} \sum_{k=1}\left(T_{k p}-D_{k p}\right)^{2}
$$

とする．ここで， $T_{k p}$ は学習パターン $p$ に関するユニット $k$ の教師データ， $D_{k p}$ は学習パターン $p$ に関するユニッ 卜 $k$ の出力データである. なお，図 4 に示すように，学習パターンは各時刻における温度測定值である。この二 ユーラルネットワークモデルを用いて, ある時間 $t$ における構造各部の温度上昇值, $\Delta t$ 時間前からその時間まで の構造各部の温度上昇值, 室温変動, $\Delta t$ 時間前からその時間までの室温変動, 冷却油温度, 稼働時間 $t$ を入力デ 一タ，その時の工作機械の熱変形を教師データとして学習を行う。ここでは，入力として使用した冷却油剤温度 設定值は，熱変形を抑制するシステムの情報である.

学習終了後のニューラルネットワークモデルに, ある時間 $t$ に測定された構造各部の温度上昇值 $\theta_{s}(t), \Delta t$ 時間 前からその時間までの構造各部の温度上昇值 $\left\{\theta_{s}(t)-\theta_{s}(t-\Delta t)\right\}$, 室温変動 $\theta_{r}(t), \Delta t$ 時間前からその時間までの室温 変動值 $\left\{\theta_{r}(t)-\theta_{r}(t-\Delta t)\right\}$, 稼働時間 $t$ を入力し, 冷却油剂温度設定值を $\theta_{x}(t)$ とおけば, そのときの工作機械の熱変 形 $D_{k p}(t)$ は

$$
\begin{aligned}
D_{k p}(t) & =f\left\{W_{j i}, V_{k j}, \beta_{j}, \gamma_{k}, \theta_{s}(t), \theta_{s}(t)-\theta_{s}(t-\Delta t), \theta_{r}(t), \theta_{r}(t)-\theta_{r}(t-\Delta t), t, \theta_{x}(t)\right\} \\
& =\sum_{i=1}^{\substack{\text { Hiddden laver } \\
\text { number }}} \frac{V_{k j}}{1+\exp \left\{-\sum_{i=1}^{\text {number }}\left(W_{j i} \cdot I_{i}+\beta_{i}\right)\right\}}+\gamma_{k} \quad, \quad I_{i}=\left[\begin{array}{c}
I_{l} \\
I_{2} \\
I_{3} \\
\vdots \\
I_{\text {Input laver }} \\
\text { number }
\end{array}\right]=\left[\begin{array}{c}
t \\
\theta_{s}(t)-\theta_{s}(t-\Delta t) \\
\theta_{r}(t) \\
\theta_{r}(t)-\theta_{r}(t-\Delta t) \\
\theta_{x}(t)
\end{array}\right]
\end{aligned}
$$

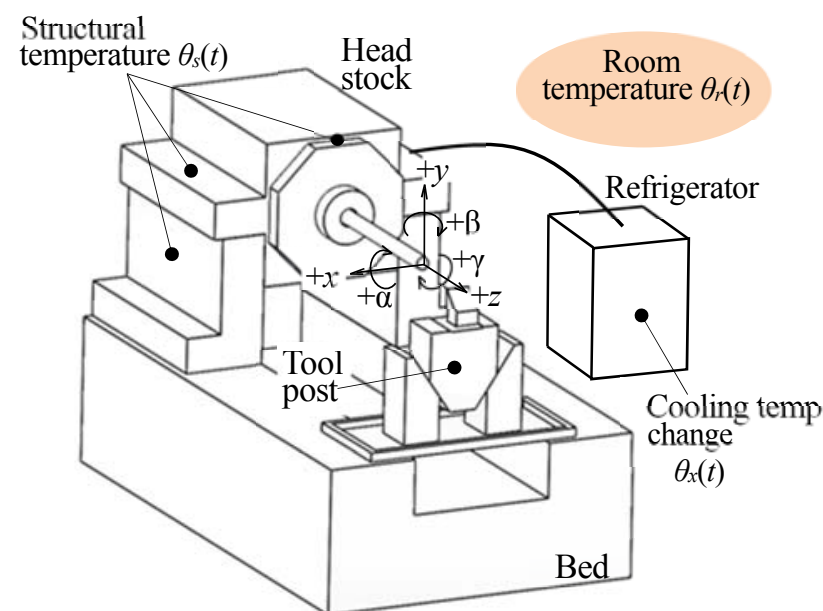

Fig.2 Model of thermal deformation on a machine tool.
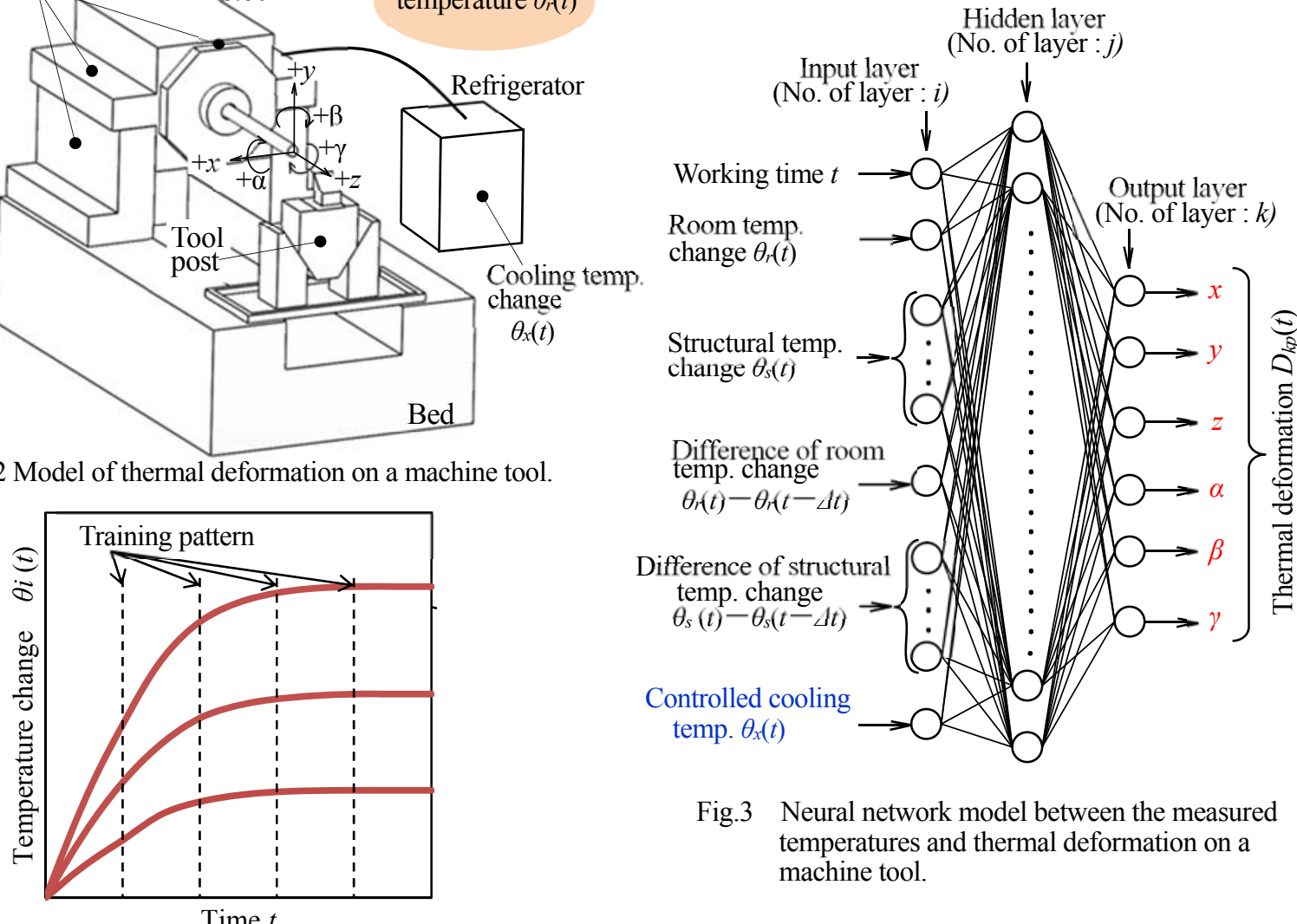

Fig.3 Neural network model between the measured temperatures and thermal deformation on a machine tool.

Fig. 4 Training pattern for neural network model. 
と表される． $W_{j i}, \quad V_{k j}, \quad \beta_{j}, \quad \gamma_{k} ， \theta_{s}(t) ， \theta_{s}(t)-\theta_{s}(t-\Delta t), \quad \theta_{r}(t), \theta_{r}(t-\Delta t), t$ はそれぞれ既知であるため，工作機械の熱 変形は $D_{k p}(t)$ は冷却油剤温度設定值 $\theta_{x}(t)$ のみの関数となる。 このようにニューラルネットワークモデルの中から 結合関数 $W_{j i}, V_{k j}$ およびオフセット值 $\beta_{j}, \gamma_{k}$ を取り出すことによって, 工作機械の熱変形と冷却油剤の温度設定值 の関係が明らかになり，『工作機械の熱変形を抑制するための冷却油の温度設定值を求める』と言う逆解法問題 を, 迅速, 容易に解くためのモデル式が構築されることになる. 最後に, 工作機械の熱変形 $D_{k p}(t)$ を最小化するた めの冷却油剤温度設定值 $\theta_{x}(t)$ を，式(2)と黄金分割探査法などを用いて計算することができる.

なお，本報では環境保全の観点から冷凍機による強制冷却は行わないため，制御因子として冷却油剤温度設定 值 $\theta_{x}(\mathrm{t})$ の代わりに，切削油剤循環経路内の冷却油剤の流量を使用することにする.

\section{4. ニューラルネットワークの逆解法を用いた熱不感機能を有する卓上旋盤の開発}

ここでは, 熱変形を抑制するために熱不感構造 (三次元零芯構造, セルフ強制冷却構造, 熱同期構造) (田辺他, 1999)が採用されている卓上旋盤を使用し, 熱同期構造の対策として冷却媒体の流量を制御するためにニューラル ネットワークの逆解法を利用する.

図 5 に実験に使用寸る卓上旋盤の概略，表 3 にその仕様をそれぞれ示す．内部の熱源は主軸前後軸受付近であ る. 本実験では熱同期構造に着目しテストバーY 方向のみの熱変形をダイヤルゲージで測定することとした．機 械構造温度は $\mathrm{T}$ 型熱電対を用いて図 5 中の丸印（の，の）に示寸 10 点を測定した. 加えて 1 点のタンク内の泠 却媒体温度測定も行っている.

図 6 に熱同期構造の卓上旋盤における湿式切削時の強制冷却システムの概略を示す．環境保全への配慮のため

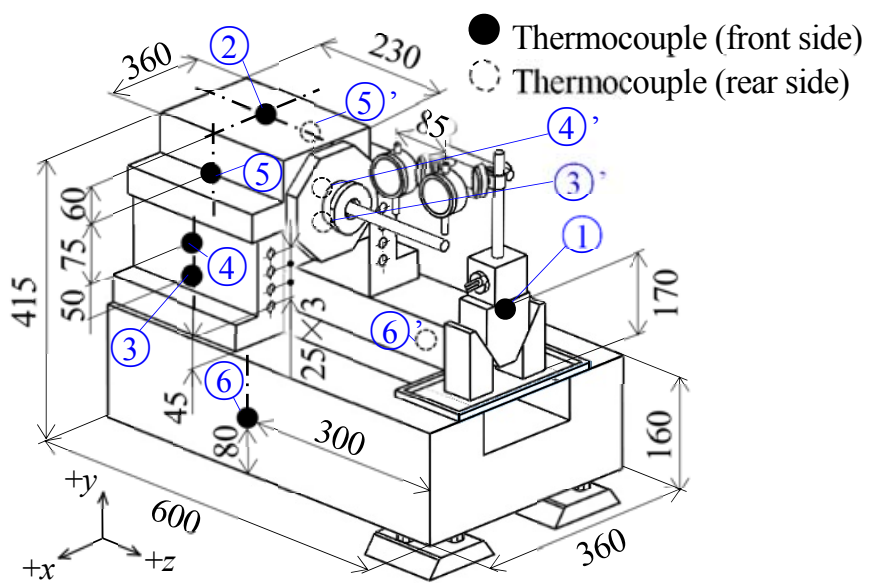

Fig. 5 Specification of the bench lathe for experiment.
Table 3 Specification of the bench lathe for experiment.

\begin{tabular}{|l|l|c|}
\hline $\begin{array}{l}\text { Head } \\
\text { stock }\end{array}$ & $\begin{array}{l}\text { Height of } \\
\text { center from bed }\end{array}$ & $177 \mathrm{~mm}$ \\
\cline { 2 - 3 } & $\begin{array}{l}\text { Height of } \\
\text { center from } \\
\text { floor }\end{array}$ & $337 \mathrm{~mm}$ \\
\cline { 2 - 3 } & Spindle speed & Max.3600 $\mathrm{min}^{-1}$ \\
\cline { 2 - 3 } & Front bearing & $50 \mathrm{BNC10TYDBB}$ \\
\cline { 2 - 3 } & Rear bearing & $45 \mathrm{BN10TYDB}$ \\
\hline Bed & Size & $600 \times 360 \times 160 \mathrm{~mm}$ \\
\hline $\begin{array}{l}\text { Tool } \\
\text { post }\end{array}$ & Stroke of Y axis & $30 \mathrm{~mm}$ \\
\hline Table & Stroke of Z axis & $200 \mathrm{~mm}$ \\
\hline Weight & & $200 \mathrm{~kg}$ \\
\hline
\end{tabular}

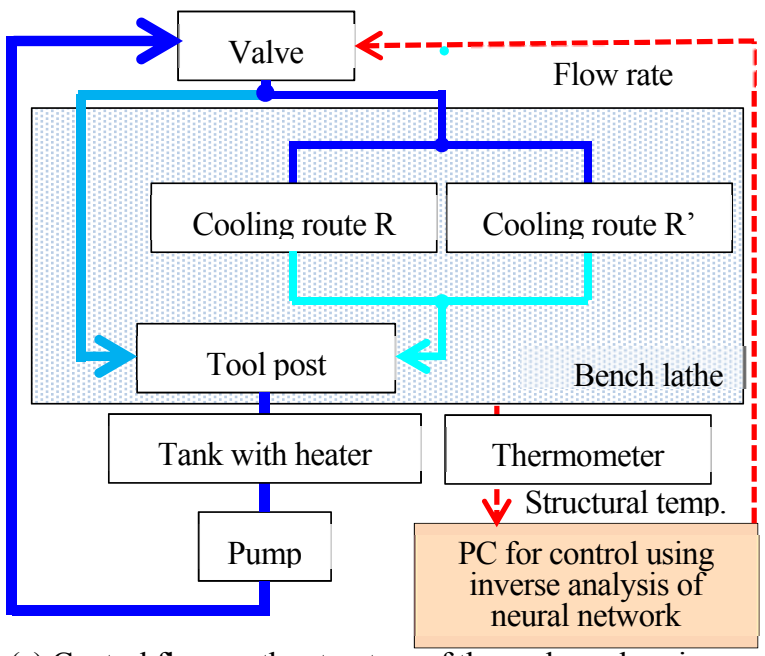

(a) Control flow on the structure of thermal synchronism

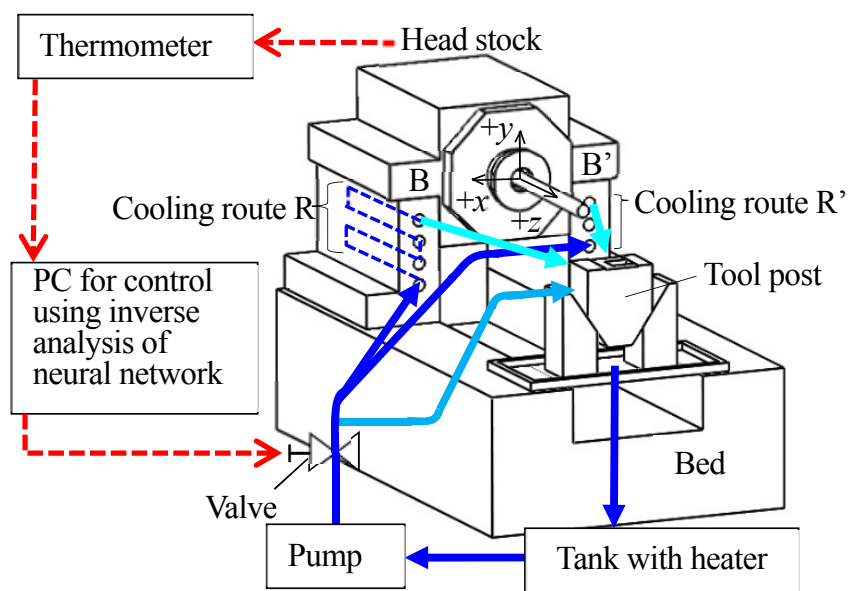

(b) Control system of fluid quantity on the structure of thermal synchronism

Fig. 6 Explanation for the control system of fluid quantity on the structure of thermal synchronism. 
に冷却媒体として pH12.5 の強アルカリ水を使用した. 強アルカリ水はタンクからポンプによって汲み上げられ, バルブによって制御され，主軸台を支持する脚 $\mathrm{B} ， \mathrm{~B}^{\prime}$ に設けられた冷却経路 R， R'に供給する流量と，そのまま 加工領域に供給寸る流量に分岐される，ここで，冷却経路 $\mathrm{R}$ と冷却経路 R’に供給される流量は同量として，主軸 台を支持する脚 $\mathrm{B}$ と B'の熱変形量に差が出ないようにする. そして, 強アルカリ水の流量変化によって, 冷却経 路 R, R'の熱伝達率を制御し, 主軸台を支持する脚 $\mathrm{B}$ と $\mathrm{B}^{\prime}$ の熱変形量を制御する. その後, 冷却経路 R と R'か ら吐出した強アルカリ水は加工領域に供給され, 最終的にはタンクに戻る. その際, 卓上旋盤の構造温度をパー ソナルコンピュータに送信し, 湿式切削のために利用された強アルカリ水による刃物台の熱変形量と, 主軸台を 支持する脚 B と B'の熱変形量がキャンセルするような流量をニューラルネットワークの逆解法によって算出し 制御を行う. 実験では, 主軸台の熱変形対策は, 使用する卓上旋盤の三次元零芯構造とセルフ強制冷却構造(田辺 他，1999)で行うことを想定して，ここでは，主軸回転と送りは行わないこととした．なお，著者らの過去の論文 (田辺他, 1999), (田辺他, 2016)の実験の際に, 主軸回転ありで刃物台への冷却油剤供給もありの場合の熱変形が, 主軸回転ありで刃物台への泠却油剤供給なしの場合の熱変形挙動に, 主軸回転なしで刃物台への泠却油剤供給あ りの場合の熱変形挙動を重畳した結果であった.

表 4 にニューラルネットワークモデルの教師データを採集するための実験パラメータを示す. 実験は $20^{\circ} \mathrm{C} \pm$ $1^{\circ} \mathrm{C}$ 恒温室で行っている. 強アルカリ水の全流量は最大 $4.5 \mathrm{l} / \mathrm{min}$ とした. これは, 森精機 NV4000DCG【ポン プは富士電機製 VKA382A】の場合で 1 系列の強制冷却最大流量 $4.5 \ell / m i n$ を模したもので, 本報の卓上旋盤で は流量が大きいが,一般的な工作機械の冷却油剤供給量としては妥当的と考える. また, 主軸台を支持する脚 B, B'に設けられた冷却経路 R, R'に供給寸る流量を 0 l $/ \mathrm{min}$ から 3.0 l/min の間で変化させた. 図 7 に示すように, 加工条件の変化を想定して切削発熱が変化することをタンク内のヒータ発熱の 4 つのパターン Case A, Case B, Case C, Case D で模擬している. ここで, Case A, Case B, Case C はタンク内に設けたヒータの発熱によって温 度調整されており，Case D はヒータを発熱させず，ポンプの発熱によってのみ温度上昇させた条件である.

図 8 に熱変形挙動の実験結果の一例を示す. これは強アルカリ水の全流量 $4.5 \mathrm{l} / \mathrm{min}$, 主軸台を支持する脚 $\mathrm{B}$, B’に設けられた冷却経路 R， R'に供給する流量を 0.25 l/min，タンク内のヒータの発熱は Case A のときの測定結 果である.このデータセットから 15 分おきに 20 個の学習データを採取した. また，すべてのデータセットに対 しても同様の学習データを採取した。

図 9 に採取したデータを使用して構築したニューラルネットワークモデルを示寸. 入力層のユニット数は, 室 温変動 1 個, 15 分前からその時間までの室温変動 1 個, 構造部の温度上昇 6 個, 15 分前からその時間までの構 造各部の温度上昇 6 個, タンク内の強アルカリ水温度上昇 1 個, 15 分前からその時間までの強アルカリ水温度上 昇 1 個, 実験時間 1 個に, 刃物台に供給された切削油剤の流量 1 個, 冷却経路 $\mathrm{R}, \mathrm{R}$ ' に供給される切削油剂の 流量 1 個の合計 19 個とした. 中間層のユニット数は入力層のユニット数の約 2 倍の 40 個とした. 出力層のユニ ット数は, $\mathrm{Y}$ 方向熱変形量 1 個とした. ニューラルネットワークを構築するためのデータ数は 464 セット（=デ ータセット $16 \times$ 学習パターン 29) であった. データ採取間隔 $\Delta \mathrm{t}$ は, 機械サイズ (熱容量) と加工条件の変化の 程度によって, 適宜変更する必要がある.

図 10 に誤差関数 $E_{p}$ (式(1)参照) と繰り返し学習回数の関係を示寸. これは, 上記のニューラルネットワークモ デルで, データセット 16, 学習パターン 29 の学習を遂行している過程である. 248 回の学習によって誤差関数

Table 4 Experimental parameter for making the neural network model.

\begin{tabular}{|c|c|c|}
\hline \multicolumn{2}{|c|}{$\begin{array}{c}\text { Total quantity of strong alkaline } \\
\text { water } \ell / \mathrm{min}\end{array}$} & $0,4.5$ \\
\hline $\begin{array}{c}\text { Quantity of } \\
\text { strong } \\
\text { alkaline } \\
\text { water } \\
\ell / \mathrm{min}\end{array}$ & Cooling route R & $0,0.125,0.25,1.5$ \\
\cline { 2 - 3 } & Cooling route R' & $0,0.125,0.25,1.5$ \\
\hline
\end{tabular}

[DOI: 10.1299/transjsme.16-00449]

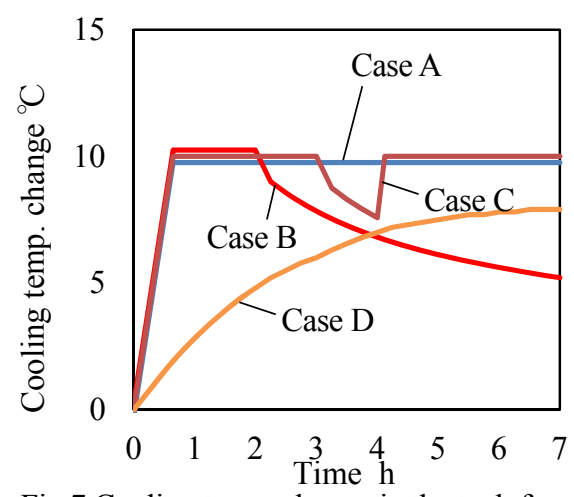

Fig.7 Cooling temp. change in the tank for making the neural network model. 


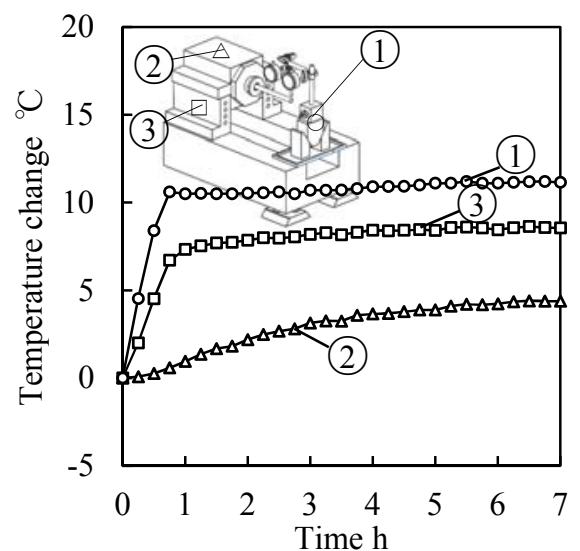

Fig.8 Temperature change on the bench lathe.

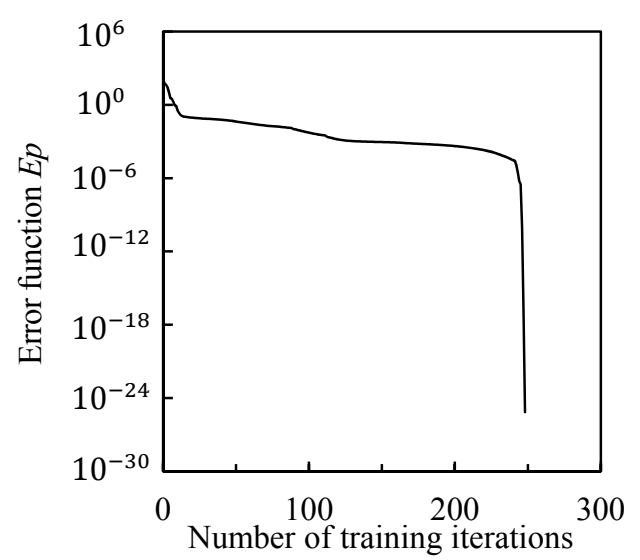

Fig.10 Convergence of error on learning process.
Working time $t$

Room temp. change $\theta_{r}(t)$

$\left.\begin{array}{c}\text { No.1 } \\ \vdots \\ \text { No.6 }\end{array}\right] \begin{aligned} & \text { Structural temp. } \\ & \text { change } \theta_{s}(t)\end{aligned}$

Difference of room temp. change $\theta_{r}(t)-\theta_{r}(t-\Delta t)$

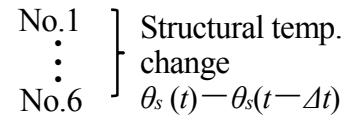

Cooling temp. change $\theta_{x}{ }^{\prime}(t)$

Difference of cooling temp. change $\theta_{x}^{\prime}(t)-\theta_{x}^{\prime}(t-\Delta t)$

Total quantity of strong alkaline water $Q_{\text {total }}$

Quantity of strong alkaline water in the cooling route $\mathrm{R}$ and $\mathrm{R}$ ' $Q_{\mathrm{loc}}$

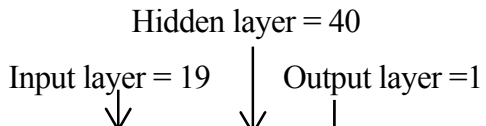

Fig.9 Neural network model between the measured temperatures and thermal deformation on the bench with the structure of zero-center on three directions and the structure of thermal synchronism.

$E_{p}$ の值が $6.9 \times 10^{-26}$ まで小さくなっており, 収束したものと考えられる. このことから, このニューラルネット ワークモデル（データ数 464 セットのモデル）を逆解法用もツールとして採用した．なお，データ数を選択して 入力した場合についても同様の収束が確認された. また，中間層のユニット数を少なくすると誤差関数 $E_{p}$ の収束 が悪くなった.

上記のニューラルネットワークモデルを用いて逆解法を行う。この時点で既知の值である結合関数 $W_{j i}, V_{k j}$ お よびオフセット值 $\beta_{j}, \gamma_{k}$ を用いて，冷却経路 $\mathrm{R} ， \mathrm{R}$ ' に供給される切削油剤の流量 $Q_{\text {local }} \ell / \mathrm{min}$ とそのときの卓上 旋盤の熱変形 $D_{k p}(t)$ の関係を表すと

$$
\begin{aligned}
& D_{k p}(t)=f\left\{W_{j i}, V_{k j}, \beta_{j}, \gamma_{k}, t, \theta_{r}(t), \theta_{s}(t), \theta_{x}^{\prime}(t), \theta_{r}(t)-\theta_{r}(t-\Delta t),\right. \\
& \left.\theta_{s}(t)-\theta_{s}(t-\Delta t), \theta_{x}^{\prime}(t)-\theta_{x}^{\prime}(t-\Delta t), Q_{\text {total, }}, Q_{\text {local }}\right\} \\
& =\sum_{j=1}^{40} \frac{V_{k j}}{1+\exp \left\{-\sum_{i=1}^{19}\left(\boldsymbol{W}_{j i} \cdot I_{i}+\beta_{i}\right)\right\}}+\gamma_{k} \quad, \quad I_{i}=\left[\begin{array}{c}
I_{1} \\
I_{2} \\
I_{3} \\
\vdots \\
I_{19}
\end{array}\right]= \\
& =\left[\begin{array}{c}
t \\
\theta_{s}(t) \\
\theta_{r}(t) \\
\theta_{x}^{\prime}(t) \\
\theta_{s}(t)-\theta_{s}(t-\Delta t) \\
\theta_{r}(t)-\theta_{r}(t-\Delta t) \\
\theta_{x}{ }^{\prime}(t)-\theta_{x}^{\prime}(t-\Delta t) \\
Q_{\text {total }} \\
Q_{\text {local }}
\end{array}\right]
\end{aligned}
$$

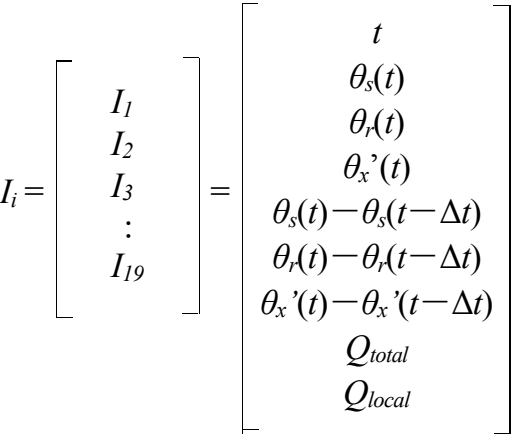

\section{となる．なお，実験では $\Delta t$ を 15 分とした。}

卓上旋盤をさまざまな条件で稼働させ, ある時点 $t$ の各温度上昇值, 15 分前からその時間までの各温度上昇值, 各流量のデータを採取し, 式(3)に代入すれば, 冷却経路に供給される切削油剤の流量 $Q_{\text {local }} \ell / \mathrm{min}$ とそのときの卓 上旋盤の熱変形 $D_{k p}(t)$ のの関係式となり，この式と黄金探索法を用いて，卓上旋盤の熱変形 $D_{k p}(t)$ の 2 乗和を最 小化するための泠却経路 $\mathrm{R}, \mathrm{R}$ ’ に供給される切削油剤の流量 $Q_{10 \mathrm{oca}} \ell / \mathrm{min}$ を計算できるようになり，それに基づ いて制御を行うことができる. 


\section{5.＼cjkstart熱不感機能を有する卓上旋盤の熱変形特性の評価}

ここでは，図 5 の卓上旋盤を用いて本手法の評価を行う．実験は主軸回転数と送りを停止させて行った．各温 度測定を 15 分おきに行い，そのデータと式(3)を使用して, 卓上旋盤の熱変形 $D_{k p}(t)$ の 2 乗和を最小化するための 冷却経路 R, R' に供給される強アルカリ水の流量 $Q_{\text {local }} \ell / \mathrm{min}$ をパーソナルコンピュータで計算する. その後, 計算結果に従ってバルブを調整し, 冷却経路 $\mathrm{R}, \mathrm{R}$ ' に供給される強アルカリ水の流量 $Q_{\text {local }} \ell / \mathrm{min}$ を変化させる. その際，冷却経路 R，R'に流さない分は，直接加工領域に誘導して吐出する.

まず, ニューラルネットワークの逆解法による制御がない場合について実験を行った. 図 11 にそのときの実験 結果を示す.このときタンク内のヒータは発熱させていない. 2 時間で $5^{\circ} \mathrm{C}$ 程度強アルカリ水の温度が上昇してお り，これは使用したポンプの発熱の影響である．その強アルカリ水の温度上昇の影響で刃物台が上方（Y 方向） に熱変形し, 主軸台を支持寸る脚部の冷却経路 R, R’に強アルカリ水を流入させない場合 (Conventional lathe) は, $\mathrm{Y}$ 方向の相対変位が大きくなっている. しかし, 主軸台を支持する脚部の冷却経路に $0.25 \mathrm{l} / \mathrm{min}$ の流量で強アル カリ水を流入させた場合は，Y 方向の相対変位が小さくなっており，さらに，主軸台を支持する脚部の冷却経路 に $3.0 \mathrm{l} / \mathrm{min}$ の流量で強アルカリ水を流入させた場合は, $\mathrm{Y}$ 方向の相対変位は正の值となっている. これは, 適切 な制御を行うことでY方向の相対変位を極めて小さくできる可能性があることを示している.

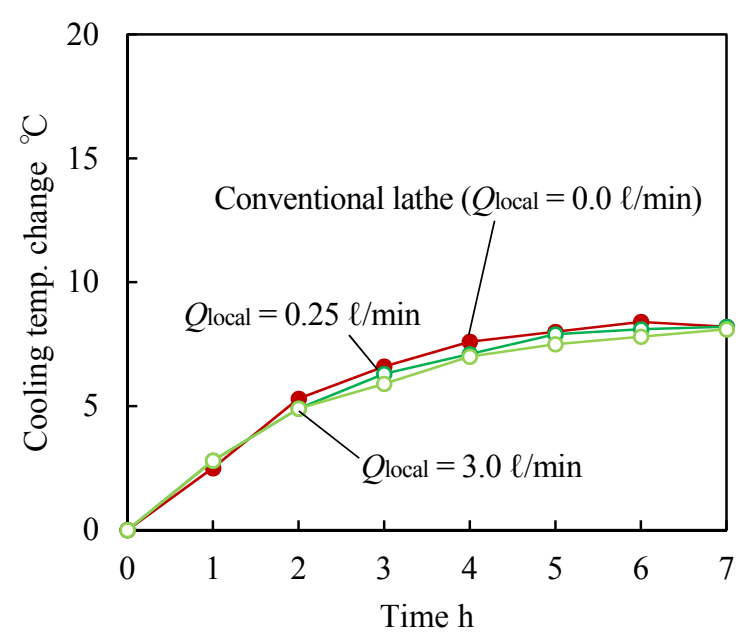

(a) Cooling temperature change

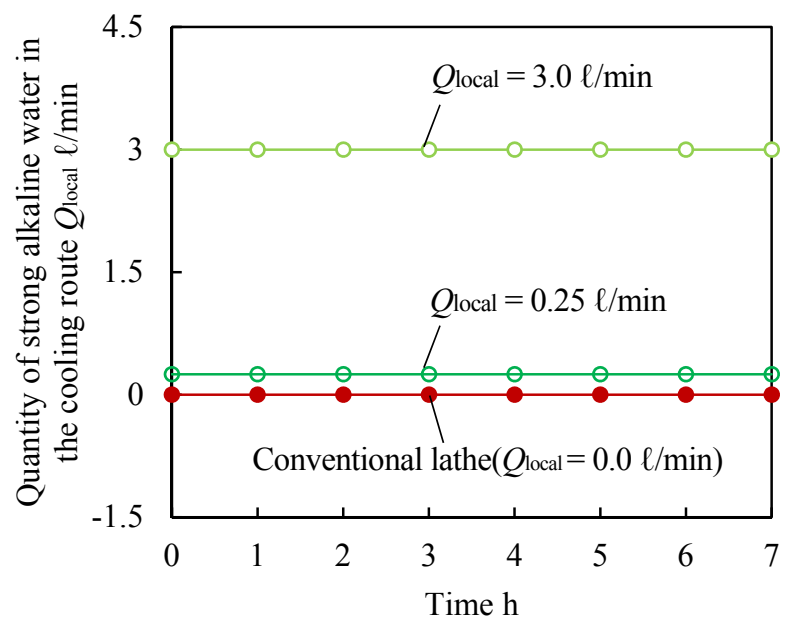

(c) Quantity of strong alkaline water

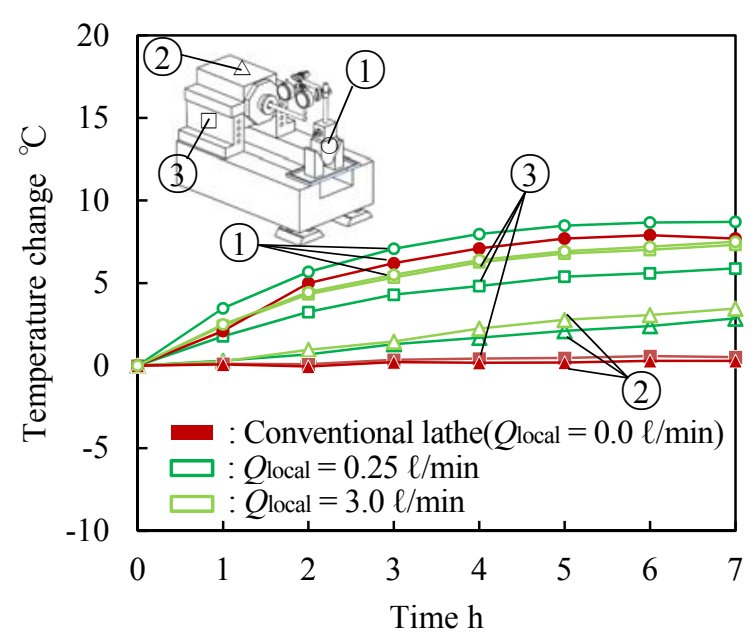

(b) Temperature change

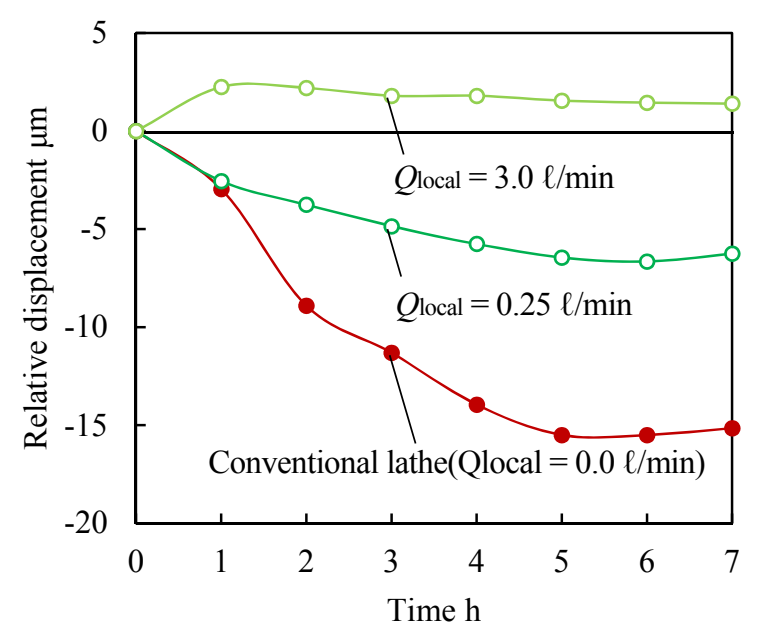

(d) Displacement $\Delta \mathrm{Y}$

Fig. 11 Thermal deformation of the bench lathe at No-countermeasure. 


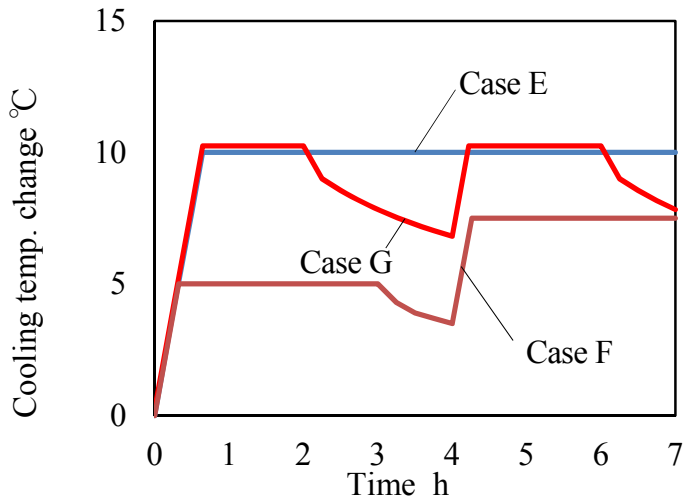

Fig.12 Cooling temp. change in the tank for evaluating the proposed system.
Table 5 Experimental parameter for evaluating the proposed system.

\begin{tabular}{|c|c|c|c|}
\hline No. & $\begin{array}{c}\text { Cooling } \\
\text { temp. } \\
\text { change }\end{array}$ & $\begin{array}{c}\text { Total quantity of } \\
\text { strong alkaline } \\
\text { water } Q_{\text {total }}\end{array}$ & $\begin{array}{c}\text { Idling time } \\
\text { (Heater in } \\
\text { tank:OFF) }\end{array}$ \\
\hline I & Case E & $4.5 \ell / \mathrm{min}$ & - \\
\hline II & Case F & $4.5 \ell / \mathrm{min}$ & $\begin{array}{c}\text { Between } 3 \text { and } 4 \\
\text { hours }\end{array}$ \\
\hline III & Case G & $3.0 \mathrm{l} / \mathrm{min}$ & $\begin{array}{c}\text { Between } 2 \text { and } 4 \\
\text { hours }\end{array}$ \\
\hline
\end{tabular}

つぎに, ニューラルネットワークの逆解法による制御がある場合について 3 つの実験を行った. 図 12 と表 5 に 示すように，異なる 3 種類の切削を模擬してタンク内の水温を変化させた．実験 I の使用したタンク内の冷却油 剂温度変動 Case E は，ニューラルネットワークの学習の際に使用した Case A と同条件である. 実験 II と III で使 用したタンク内の冷却油剤温度変動 Case F と Case G は，学習させた温度範囲内で教師データと異なる発熱パタ ーンである.さらに，実験 III では強アルカリ水の全流量を 3.0 l/min に変更した場合の条件である.

図 13 に実験 I, 図 14 に実験 II, 図 15 に実験 III の場合の熱変形挙動の実験結果をそれぞれ示す. 各図のパラ メータはいずれも, 冷却経路 R, R'に強アルカリ水を供給しない場合 (Conventional lathe), 提案システムを使用 せず冷却経路 R， R’ に一定流量の強アルカリ水を供給した場合，提案したシステムを使用した場合の 3 種類で

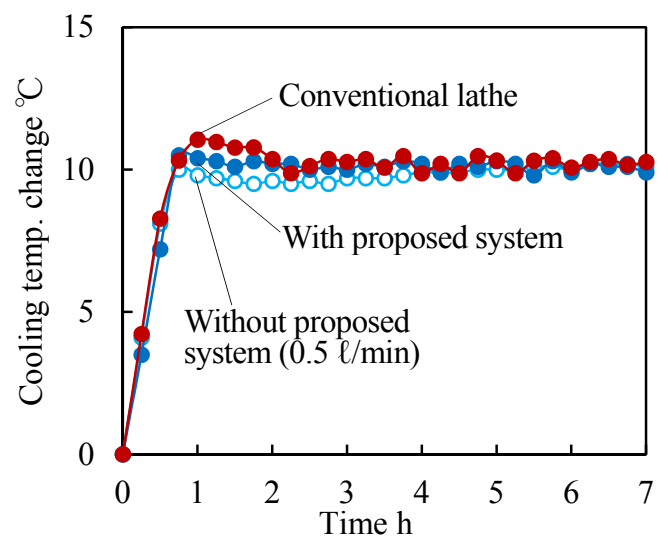

(a) Cooling temperature change

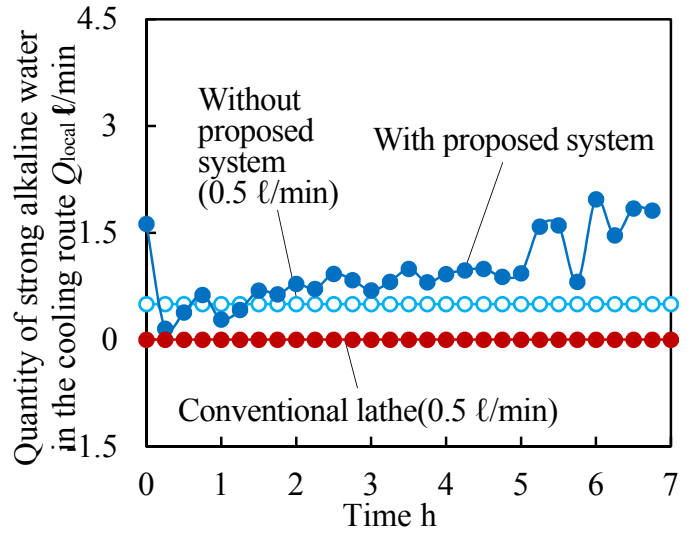

(a) Quantity of strong alkaline water

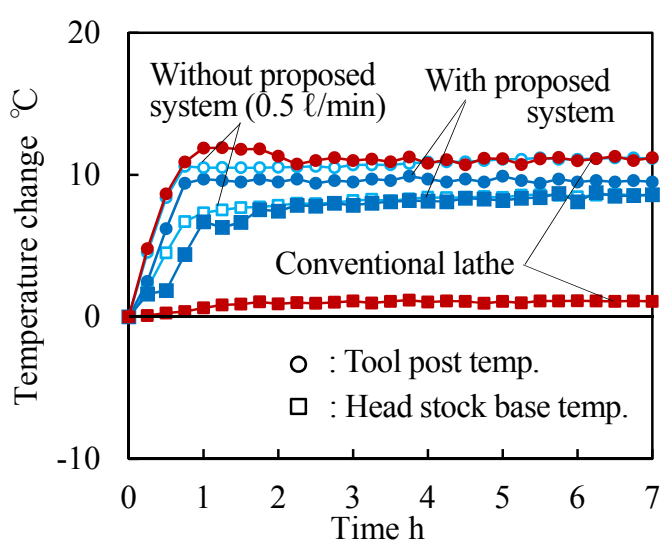

(b) Temperature change

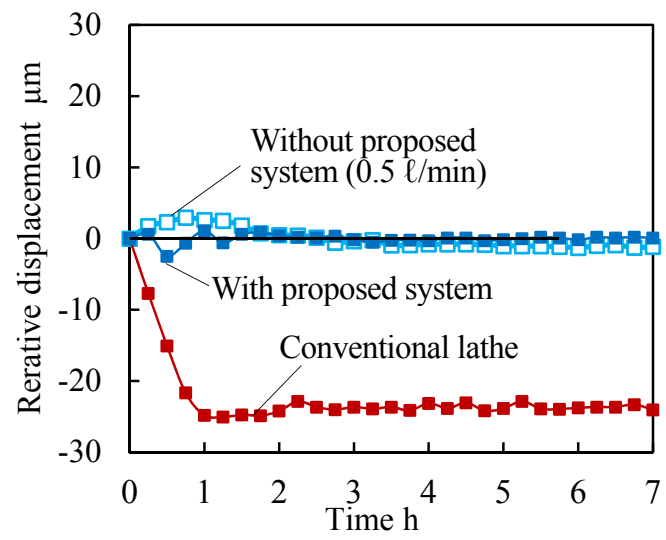

(d) Displacement $\Delta Y$

Fig. 13 Thermal behaviour of the bench lathe (Experimental No. I ; Cooling temp. change Case E). 


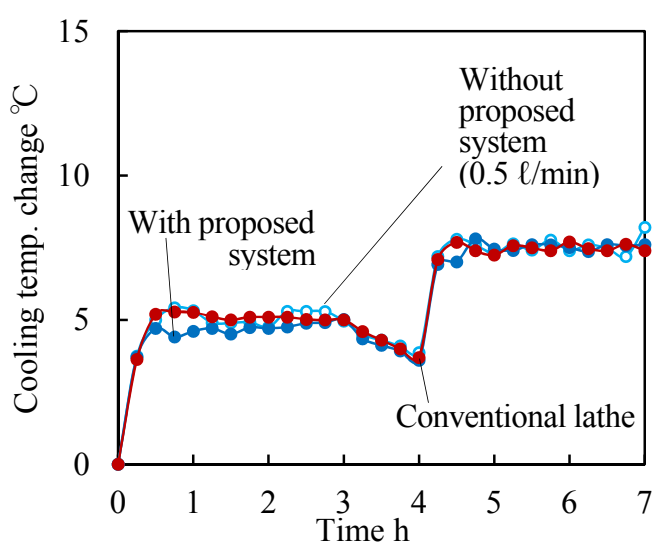

(a) Cooling temperature change

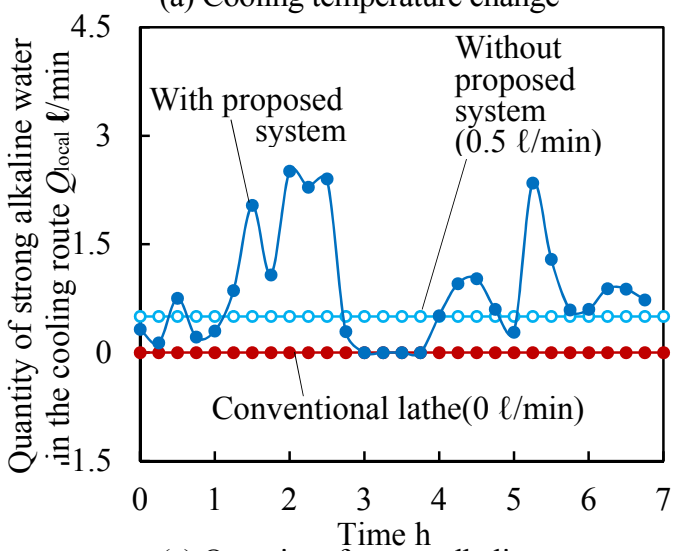

(c) Quantity of strong alkaline water

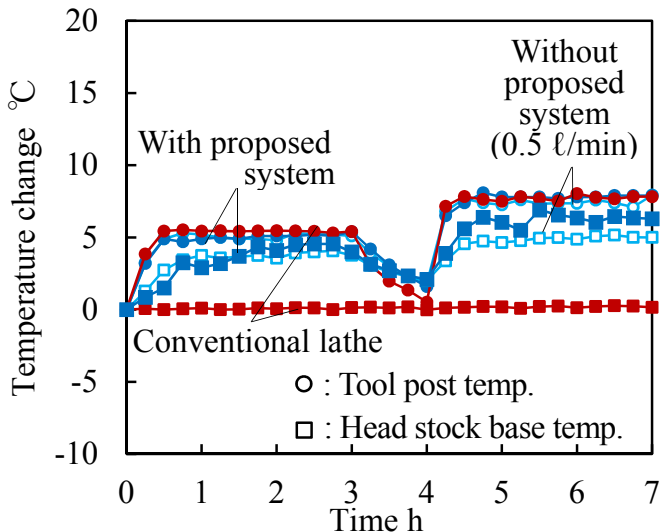

(b) Temperature change

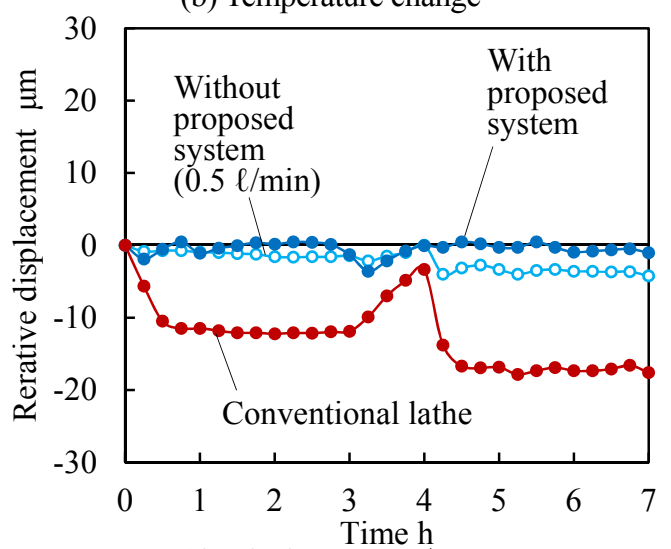

(d) Displacement $\Delta \mathrm{Y}$

Fig. 14 Thermal behaviour of the bench lathe (Experimental No. II ; Cooling temp. change Case F).

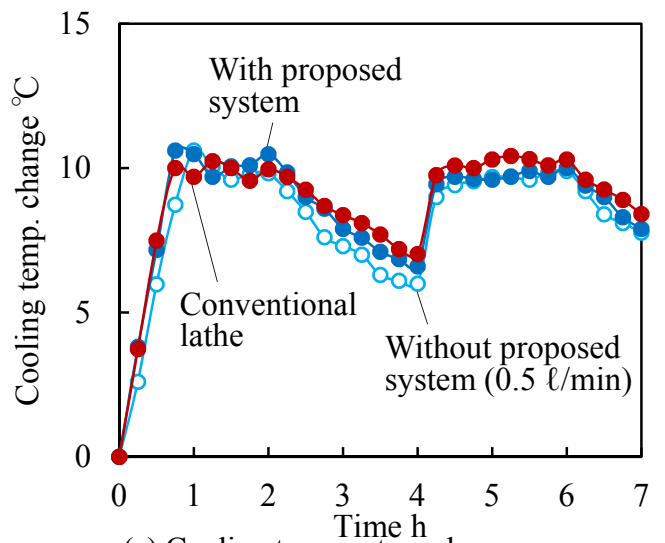

(a) Cooling temperature change

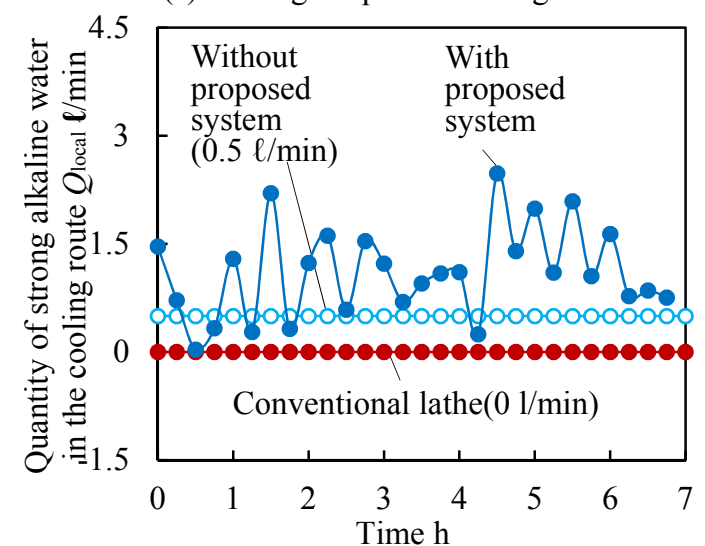

(c) Quantity of strong alkaline water

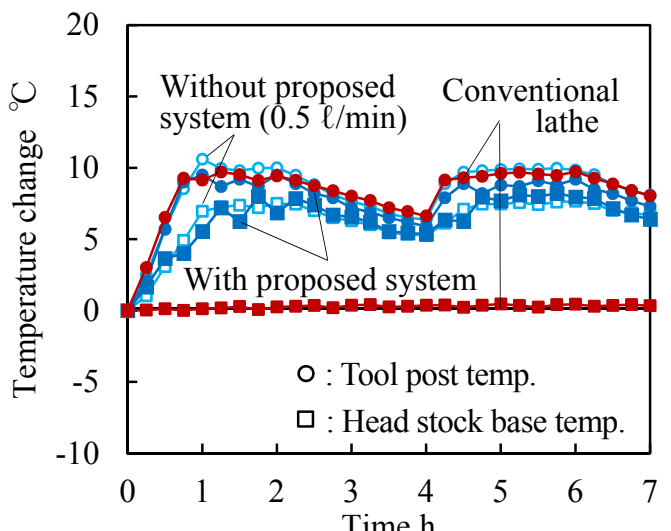

(b) Temperature change

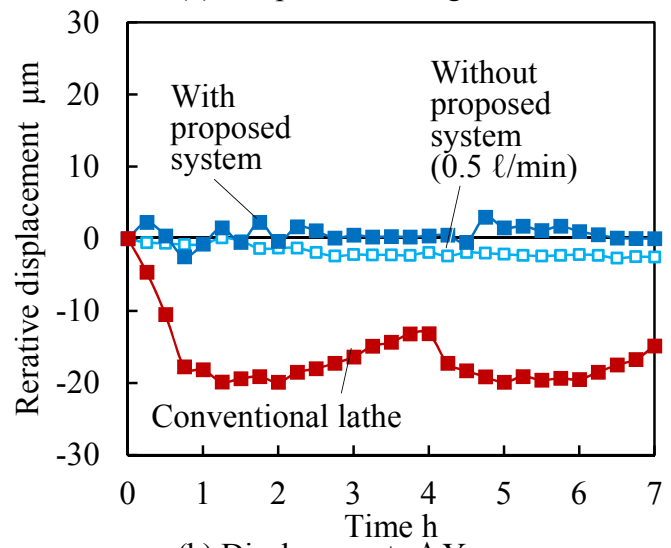

(b) Displacement $\Delta Y$

Fig. 15 Thermal behaviour of the bench lathe (Experimental No. III ; Cooling temp. change Case G). 
ある。ここで，提案したシステムを使用せず冷却経路 R， R' に一定流量の強アルカリ水を供給した場合の流量 は, 実験の中で $\mathrm{Y}$ 方向の熱変形が最も小さくなった $Q_{\text {local }}=0.5 \mathrm{l} / \mathrm{min}$ を使用した. また, 図(a)はタンク内の強ア ルカリ水温の経時変化, 図(b)は主軸台と刃物台の構造温度の経時変化, 図(c)は冷却経路 R, R' に供給される強 アルカリ水の流量 $Q_{\text {local }} \ell / \min$ の経時変化, (d)はY 方向の相対変位の $\mathrm{Y}$ 方向の経時変化をそれぞれ示す.

切削を模擬したヒータの発熱パターンごとに強アルカリ水温度の経時的变化が異なるため, 機械構造の温度分 布は大きく異なっているが，いずれの発熱パターンにおいても冷却経路 R, R'に強アルカリ水を供給しない場合

（Conventional lathe）の実験結果よりも，熱同期構造を適用した結果の方が熱変形を抑制できていることがわか る.また，熱同期構造において一定流量を流した場合よりも，提案したシステムの方がより熱変形を抑制できて いる. さらに，主軸台を支持する脚部の冷却経路に 3.0 l/min（学習した範囲内）の流量で強アルカリ水を流入さ せた場合でも，提案したシステムは十分に対応していた. 本報で提案した制御手法によって，Y方向の熱変形は 経時的に $3 \mu \mathrm{m}$ 以下に抑制できおり, ニューラルネットワークの逆解法が効果的に利用されていると考えられる.

ニューラルネットワークでは, 教師データの範囲内でないと推定精度が著しく低下寸る. 今回の教師データの 最大值はそれを考慮して設定した，そのため, 確認実験ではその範囲内での変動にとどまっている．また，今回 は考慮していないが, 主軸台の発熱がベッドまで熱伝導してそれが冷却油剤の温度上昇に影響するときでも, 二 ユーラルネットワーク構築の際にその影響を容易に含有できると考える. また，ニューラルネットワークには物 理的な意味はなく，制御対象の制御則を系統的に説明することが困難である. 重要なことは，教師データの上限 值と下限值の範囲内に制御対象が入っていること, 所望出力に対して因果関係の強い入力を準備すること, 中間 層の数は入力層の数の 2 倍以上にすること, 評価関数は $10^{-20}$ 以下に収束することが挙げられ, 本報では, 教師 データの上限值と下限值を実験の範囲内にセットし, 入力に温度の時間変化を入力值とし, 中間層の数を入力層 の数を約 2 倍として, 評価関数として $6.9 \times 10^{-26}$ の収束を確認している. そのため, 表 5 の実験条件 No. I, No. II, No. III の 3 つの確認実験は演習問題的に考えられるが, 学習に使用した教師データの範囲内では, 評価関数 として $6.9 \times 10^{-26}$ の精度で推定が可能であり, 教師データの範囲内で精度の良い推定が可能であり, 実用的な利 用が可能であると考える. 冷却油剤はベッド上を経由してタンクに戻っており，教師データおよび確認実験デー タにはベッドの熱変形の影響も含まれており，使用したニューラルネットワークはそれに対応していた.

なお, 本実験で熱電対が主軸台にも取り付けられているのは, 前報(田辺他, 2016)のセルフ強制冷却による主軸 台熱変形制御を同時使用することを想定しているためであり，本報のニューラルネットワーク中では冷却油剤関 連箇所の入力データのみに大きな重み（結合関数とオフセット值が大）がかかっていた．また，工作機械の熱変 形は主に構造温度に起因するため, 前報の手法と今回提案している手法を同時に行うことで, 前報と本報の熱変 形抑制効果が同時に得られると考える. その際，入力值として主軸台発熱が影響した構造温度と冷却油剤が影響 した構造温度の各データを教師データとして採用寸ることと, 教師データの中に主軸回転の有無や冷却油剤の供 給の有無などの加工で行われる範囲内の条件を加味することが重要である.

\section{6. 環境保全特性の簡単な考察}

本手法の環境負荷に対する簡単な評価に関しては，前報(田辺他，2016)と同じ手法で行い，従来法（消費電力 $1.75 \mathrm{~kW}$ 二卓上旋盤 $0.75 \mathrm{~kW}$ 泠凍機 $1.0 \mathrm{kw}$ ） と本手法（消費電力 $0.75 \mathrm{~kW}=$ 卓上旋盤 $0.75 \mathrm{~kW}$ のみ）の 1 年間（1 日 8 時間， 1 年 250 日稼働）の排出 $\mathrm{CO}_{2}$ 量のそれぞれ計算した(田辺他，2016). その結果， 1 年間稼働した場合 の排出 $\mathrm{CO}_{2}$ 量は，従来法に比べて本手法を採用することによって $1100 \mathrm{~kg}-\mathrm{CO}_{2}$ の削減効果 $(57 \%$ 削減) が得られ た.

\section{7. 結 言}

本研究の結果をまとめると以下のとおりである.

(1) 熱同期構造を，ニューラルネットワークの逆解法を用いて制御する手法を確立した.

(2) 本手法によって, 卓上旋盤の熱変形を $\Delta \mathrm{Y}=3 \mu \mathrm{m}$ に抑制することができた. 
（3） 1 年間稼働した場合の排出 $\mathrm{CO}_{2}$ 量は，従来法に比べて本手法を採用することによって $1100 \mathrm{~kg}-\mathrm{CO}_{2}$ の削減効 果 $(57 \%$ 削減) が得られた.

\section{文献}

千輝淳二，垣野義昭，工作機械の温度制御に関寸る研究（第 4 報）（旋盤とマシニングセンターの熱的特性に応じ た温度制御方法の選定)，精密工学会誌，Vol. 53, No. 4 ( 1987), pp.625-632.

e-Gov，特定排出者の事業活動に伴う温室効果ガスの排出量の算定に関する省令第 2 条 (2013), available from < http:/law.e-gov.go.jp/htmldata/H18/H18F15002002003.html > (参照日 2015 年 7 月 15 日).

金子義幸，田辺郁男，磯部稔，前田充夫，環境保全を考慮した熱変形対策による高精度旋盤の開発，日本機械学 会論文集 C 編, Vol. 70, No. 700 ( 2004), pp.3611-3616.

Mayr, J., Jedrzejewski, J., Uhlmann, E., Donmez, M. A., Knapp, W., Härtig, F., Wendt, K., Moriwaki, T., Shore, P., Schmitt,

R., Brecher, C., Würz, T. and Wegener, K., Thermal issues in machine tools, CIRP Annals - Manufacturing Technology, 61 (2012) pp.771-791.

環境省, 平成 25 年度の電気事業者ごとの実排出係数・調整後排出係数等の公表について (2013), available from< https://www.env.go.jp/press/press.php?serial=17512> (参照日 2015 年 7 月 15 日).

森脇俊道, 社本 英二, 河野 昌弘, ニューラルネットワークによる工作機械の熱変形予測 機械表面温度の時間 履歴を考慮することによる予測精度の向上，日本機械学会論文集 C 編, Vol. 61, No.584 (1995), pp.1691-1696.

下平三郎, 腐食・防食の材料科学, アグネ技術センター (1995), pp.30-32, 255-257, 287-288.

田辺郁男, 山中邦彦, 水谷淳之介, 山田泰宏, 熱変形抑制のための新しい旋盤構造設計（三次元零芯設計，七ル フ強制冷却，熱同期設計），日本機械学会論文集 C 編, Vol. 65, No. 639 ( 1999), pp.4508-4513.

田辺郁男，TRUONG HONG Mihn，吉井一夫，環境にやさしい気化熱冷却を用いた切削加工（第 1 報，気化熱冷 却の効果と旋盤チップ冷却への適用），日本機械学会論文集 C 編, Vol. 66, No. 643(2000a), pp.1026-1030.

田辺郁男, 碇山剛介, 西山 晃, 浦野好市, ニューラルネットワークの逆解法による主軸冷却油最適温度制御, 日本機械学会論文集 C 編, Vol. 66, No. 647( 2000b), pp.2443-2448.

田辺郁男，松下幸司，TRUONG HONG Mihn，セルフ強制冷却を用いた工作機械熱変形の抑制（セルフ強制冷却 モデルの構築と応用），日本機械学会論文集 C 編, Vol. 67, No. 660 ( 2001), pp.2713-2718.

田辺郁男, 折茂竜哉, 三次元測定機の室温変動に対する熱変形抑制対策（地球環境保全のための省エネルギー対 策），日本機械学会論文集 C 編, Vol. 67, No. 662 ( 2001), pp.3357-3362.

田辺郁男, 池田祥生, 浦野好市, ニューラルネットワークの逆解法による主軸冷却油最適温度の推定（再学習の 効果），日本機械学会論文集 C 編, Vol. 69, No. 679 ( 2003), pp.819-824.

田辺郁男, イエー・トット・ソー, 井山徹郎, 阿部洋太朗, 低熱伝導材料加工のためのニューラルネットワーク を用いた工具温度管理，日本機械学会論文集 C 編, Vol. 77, No. 776 (2011), pp.1556-1564.

田辺郁男，西山晃，安藤涼，高橋智，熱不感機能を有する旋盤の開発（ニューラルネットワークの逆解法を用い た制御），日本機械学会論文集 C 編, Vol. 82, No. 839 (2016), pp.1-11.

\section{References}

Chigira, J. and Kakin, Y., Study on temperature control of machine tools (4th Report) ( Selection of temeprature control methods suitable for lathes and machining centers with different thermal characteristics, Journal of the Japan Society for Precision Engineering, Vol. 53, No. 4 ( 1987), pp.625-632.

e-Gov, Ordinance related to calculation for carbon dioxide equivalent greenhouse gas emissions with their business activities of specified emitters, Article 2 (2013), available from < http://law.e-gov.go.jp/htmldata/H18/H18F15002002003.html > (accessed on 15 July, 2015) (in Japanese).

Kaneko, Y., Tanabe, I., Isobe, M. and Maeda, M., Development of a high precision lathe with countermeasure of environmental preservation for thermal deformation, Transactions of Japan Society of Mechanical Engineers, Series C, Vol. 70, No.700 (2004), pp. 3611-3616 (in Japanese).

Mayr, J., Jedrzejewski, J., Uhlmann, E., Donmez, M. A., Knapp, W., Härtig, F., Wendt, K., Moriwaki, T., Shore, P., Schmitt, R., Brecher, C., Würz, T. and Wegener, K., Thermal issues in machine tools, CIRP Annals - Manufacturing Technology, 61 (2012) pp.771-791. 
Ministry of the environment, Announcement of actual emission factor, adjusted emission per electric utility company in FY 2012 (2013), available from $<$ https://www.env.go.jp/press/press.php?serial=17512 > (accessed on 15 July, 2015) (in Japanese).

Moriwaki, T., Shamoto, A. and Kawamo, M., Estimation of thermal deformation of machine tool by applying neural network. improvement of estimation accuracy by utilizing time-series data of temperature on machine surfaces, Transactions of Japan Society of Mechanical Engineers, Series C, Vol. 61, No.584 (1995), pp. 1691-1696 (in Japanese).

Simohira, S., Material science for crrosion and its protection, AGNE Gijutsu Center Inc. (1995), pp.30-32, 255-257, 287-288 (in Japanese).

Tanabe, I., Yamanaka, K., Mizutani, J. and Yamada, Y., A new design of lathe structure for reducing thermal deformation (Design of zero-center on three directions, self-compulsory cooling and design of thermal synchronism), Transactions of Japan Society of Mechanical Engineers, Series C, Vol. 65, No.639 (1999), pp. 4508-4513 (in Japanese).

Tanabe, I., Truong, H. M. and Yoshii, K., Turning with environment-friendly cooling method using water evaporation $\left(1^{\text {st }}\right.$ report, Cooling effect of water evaporation and its applicability to tool tip cooling), Transactions of Japan Society of Mechanical Engineers, Series C, Vol. 66, No.643 (2000a), pp. 1026-1030 (in Japanese).

Tanabe, I., Ikariyama, T., Nishiyama, A. and Urano, K., Estimation of the most suitable temperature for cooling oil on a spindle using inverse analysis of nueral network, Transactions of Japan Society of Mechanical Engineers, Series C, Vol. 66, No.647 (2000b), pp. 2443-2448 (in Japanese).

Tanabe, I., Matsushita, K. and Truong, H. M., Study on self-forced cooling for reducing thermal deformation of machine tool (Modeling of self-forced cooling and its applicability), Transactions of Japan Society of Mechanical Engineers, Series C, Vol. 67, No.660 (2001), pp. 2713-2718 (in Japanese).

Tanabe, I. and Orimo, T., Countermeasure for reducing thermal deformation of a coordinate measuring machine caused by ambient temperature fluctuation (Conservation of energy for protecting the earth), Transactions of Japan Society of Mechanical Engineers, Series C, Vol. 67, No.662 (2001), pp. 3357-3362 (in Japanese).

Tanabe, I., Ikeda, S. and Urano, K., Estimation of optimum temperature for cooling oil on a spindle using inverse analysis of neural network (Effect of relearning), Transactions of Japan Society of Mechanical Engineers, Series C, Vol. 69, No.679 (2003), pp. 819-824 (in Japanese).

Tanabe, I., Ye, H. S., Iyama, T. and Abe, Y., Control of tool temperature using neural network for machining work-piece with low thermal conductivity, Transactions of Japan Society of Mechanical Engineers, Series C, Vol. 77, No.776 (2011), pp. 1556-1564 (in Japanese).

Tanabe, I., Nishiyama A., Ando R. and Takahashi, S., Development of lathe with insensibility function for thermal and temperature change (Control using inverse analysis of neural network), Transactions of Japan Society of Mechanical Engineers, Series C, Vol. 82, No.839 (2016), pp. 1-11 (in Japanese). 